\title{
The Correspondence of Wolfgang Capito, Volume 1: 1507-1523
}

Edited and translated by Erika Rummel, with the assistance of Milton Kooistra Toronto: University of Toronto Press, 2005. Pp. xlii, 285

This volume, the first of a projected three-volume set, is a most valuable resource for scholars of the Reformation in general and readers of English in particular, who have had only limited access to the letters of one of the leading reformers of Strasbourg. As Rummel tells us in the preface, there has been until now no modern edition of his correspondence, although many of his letters are available scattered throughout the critical editions of letters to and from contemporaries such as Erasmus, Luther, and others. In putting together her collection, she has profited from the work of Olivier Millet, whose Correspondance de W.F. Capiton (Strasbourg, 1982) provides a list of Capito's letters with summaries in French, and of the nineteenth-century scholar J. Baum, who oversaw a collection of transcriptions that were never published. Her own contribution, in assembling, transcribing (and, in the case of the Baum collection, retranscribing), translating, and annotating this collection, will leave generations of scholars in her debt.

As Rummel's preface also explains that this collection does not provide full translations of the complete letters, but only of those not published elsewhere in relatively accessible editions; the remainder are summarized. The project is supplemented by a website, <www.wolfgang-capito.com>, containing the original Latin (or, in some cases, German) for those letters that are included and the summaries of those that are not. Upon consulting the website, readers are advised that the transcriptions are a work in progress, and invited to contribute corrections or comments. Thus both volume and website, as they complement one another, represent new pathways that are opened up by the Internet.

That Capito's correspondence should have suffered from such neglect is curious, considering his importance as a reformer: he was, along with Martin Bucer, a leader of religious reform in Strasbourg. Like many other reformers, Capito progressed from being an advocate of a moderate, humanistic reform to becoming a convert to the evangelical reform, a shift that is encompassed in the period of this volume. We find him early on championing Erasmus against his critic Edward Lee, while receiving praise in a letter of March 1520 from Oswald Myconius as "the only man who, next to our Erasmus, the restorer of all good studies and especially of Christian theology, sustains humane letters and wonderfully promotes that true Christianity." Capito began his career as a priest and a theologian, receiving a doctorate in theology from the University of Freiburg. In 1515 he received an appointment in Basel, where he joined a group of scholars at the Froben Press, including Johannes Oecolampadius, 
Conradus Pellicanus, and of course, Desiderius Erasmus. From Basel he took an appointment in 1520 as cathedral preacher in Mainz, where he acted as advisor to the archbishop, Albert of Brandenburg, until moving to Strasbourg in 1523.

At the time of his appointment at the archbishop's court he had already come to admire Martin Luther, but he kept his inclinations hidden as he attempted to work indirectly by influencing his master to deal leniently with the reformers, and in turn by presenting the archbishop in as positive a light to them as possible. A letter in mid-1521 to Bonifacius Wolfhart is a case in point: "For I find in him [the archbishop] the consummation of all natural talent and fortune, and yet he has not compromised his morals on account of his wealth." At around the same time, Capito enumerated in a report to the archbishop a list of arguments against taking on the post of papal legate, which would involve him directly in the enforcement of the Edict of Worms. Never before in recent memory has such a dangerous commission been given by Rome to Germany, Capito writes, for Luther has won widespread support, in an enterprise that "is reinforced by the manifest abuse, deceit, and oppression practiced by the legates sent from Rome," and any attempt at suppressing him would bring only failure, hostility, and war. Many other entries testify to Capito's wish that Luther himself would temper his criticisms in the interests of bringing about change peacefully. Needless to say, his efforts were fruitless. Like Erasmus, Capito found himself in the position of being strongly admonished on all sides because of his reluctance to declare himself as either a papist or a reformer.

In addition to selections from Capito's personal correspondence, Rummel has included letters from the archbishop that Capito drafted on his behalf. Much of this correspondence concerns the business of patronage and bestowing of benefices; indeed, Capito himself underwent a lengthy process of petitioning Rome for the provostship of St. Thomas in Strasbourg against rival claimant Jacob Abel (an appendix includes documents relating to this dispute). This endeavor involved him in complex manoeuvres for approval by the pope and his representatives; Girolamo Aleandro wrote in late 1522 that the pope would expedite his claim but in return expected Capito's loyalty to the "peace and tranquillity and order of the Catholic Church.” Throughout 1523, the question of Capito's loyalties dominates the correspondence, including three letters of admonishment from Sélestat humanist Jacob Wimpheling deploring rumors he has heard about Capito's defection from Roman teaching, and the preface to Capito's Apology justifying his step of taking out citizenship in Strasbourg, an act that was at that time tantamount to an announcement of support for the Reformation (letter 175). Other highlights of the volume include two early poems that Capito wrote in praise of Johannes Eck (letters 1a and 3a), a 
1517 educational manifesto addressed to Johann Rudolf von Hallwyl (letter 8), and Johannes Cellarius' eyewitness account of the Leipzig Disputation (letter 31).

Rummel modestly describes her work in this project as a bridge, and she is correct in the sense that these volumes will not provide translated texts of the complete correspondence. Nonetheless, this is a brilliant achievement by virtue of the thoroughness of Rummel's scholarly apparatus. Readers of this volume will have the pleasure of engaging with one of the keenest minds in Reformation studies along with the correspondence of Wolfgang Capito.

LAURel CARrington, St. Olaf College

\section{William B. Jordan}

\section{Juan van der Hamen y León \& the Court of Madrid}

New Haven and London: Yale University Press, 2005. Pp. 333

Juan van der Hamen y León \& the Court of Madrid challenges any lingering notion of Philip IV's court as a dark and dreary place illuminated only by the bright talent of Velázquez. In the 1620 s, the concentration in Madrid of discerning patrons and talented painters eager to bring Spanish art to parity with Italian art and raise their own status in the process was stimulating an overdue renewal. Juan van der Hamen (1596-1631), by his mixed Spanish-Flemish pedigree, his location in Madrid, and his close connections to the taste-making literati, was poised to contribute to the transformation in the pictorial arts. In short informative chapters Jordan sketches in the details of Van der Hamen's swift rise to fame and the discerning aesthetes who sponsored him: the Comte de Solre, the Marqués of Leganés, the Cardinal-Infante Don Fernando, and the Italian delegation of Cardinal Francesco Barberini. Prolific and precocious, Van der Hamen communicates the energy of the Madrid art scene in a transitional decade that Jordan rightly calls "the most interesting years of the seventeenth century."

Van der Hamen distinguished himself in Madrid principally as a painter of still lives, and it is this aspect of his work that gets the greatest amount of attention from Jordan. His prose is a pleasure to read. Describing Boxes of Jars of Sweets in Granada he says, "Each of the forms is a simple but powerful geometric shape-a cylinder or a sphere-but the strong light models the simple forms boldly, emphasizing the particular surface quality of each: the grain of the wood, the metallic hardness of the tiny black nails, the rough glaze of the pot, and the dull sheen of the silver spoon." Jordan identifies some still lives with items in the death inventory of the Marqués of 